\title{
JUURNAL.RU
}

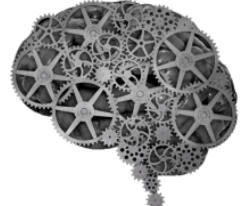

COMPANY GROUP

"INTELLEKT"

Узденова К.Ч.

Северо-Кавказская Государственная Гуманитарно-Технологическая Академия

Черкесск, Россия

doi: 10.18411/1j2016-4-47

\section{Развитие АПК в КЧР}

Общая цель управления инновационным развитием - качественное обновление аграрной сферы экономики, отвечающее требованиям увеличения производства сельскохозяйственной продукции, повышения уровня жизни сельского населения, роста эффективности агропромышленного производства, сохранения окружающей среды. Достижение этой цели предполагает решение широкого круга задач, важнейшие из которых: создание инноваций с потенциалом, позволяющим достичь и превзойти лучшие результаты в мировой практике агропромышленного производства; сокращение периода прохождения нововведений от создания до практического применения; придание процессу освоения научнотехнических достижений массового и необратимого характера; эффективное использование направляемых на инновационное развитие АПК средств и ресурсов. Необходимы соответствующие задачам инструменты воздействия на субъекты инновационной деятельности: эффективно функционирующий рынок научнотехнической продукции и активно используемый административный ресурс [1].

Однако, ключом развития инновационной деятельности должна стать разработка стратегической программы развития региона, в котором использование инноваций будут стержнем, определяющий тактику достижения поставленных целей. На начальном этапе построения такой стратегической программы возникает необходимость разработки концептуальных положений инновационного развития региона. 
Концепция в данном аспекте нами понимается как генеральный замысел, определяющий стратегию действий при осуществлении плана стратегии инновационного развития региона.

Разработка основных концептуальных направлений инновационной деятельности в агропромышленном производстве является основой подготовки нормативно-правовых документов, выработки инновационной политики в регионе. Основная задача государственной инновационной политики и деятельности в АПК региона состоит в использовании научных знаний и разработок, воплощенных в новый или усовершенствованный продукт, технологический процесс, в новые формы организации производства и управления, используемые в практической деятельности и приносящие различные виды эффекта. Разработка стратегии региона базируется на стратегии развития АПК страны и особенностей сложившегося экономического уклада региона. Далее на основе анализа экономического состояния региона определяется его экономический потенциал, намечаются стратегические цели, разрабатываются индикаторы развития и механизмы решения поставленных задач для достижения цели.

Понятие стратегия подразумевает соотношение целей и средств социально-экономического развития в долгосрочной перспективе.

Основной целью стратегии устойчивого развития КЧР до 2030 года, на наш взгляд, является достижение высокого уровня жизни, соответствующего европейским стандартам, формирование конкурентоспособной высокотехнологичной инновационной экономики, обеспечивающий устойчивое и сбалансированное развитие с учетом социокультурных практик этносов КарачаевоЧеркесской Республики в составе народнохозяйственного комплекса России [2].

Целью устойчивого функционирования сельского хозяйства КЧР является производство экологически чистой продукции удовлетворяющей потребности населения в продовольствии, организации эксперта экологически чистых продуктов за пределами республики, удовлетворения туристско- рекреационного комплекса в обеспечении продуктами питания, удовлетворяющие как по цене, 
ассортименту и качеству туристов и в конечном итоге обеспечение устойчивого социально-экономического развития сельских территорий. Таким образом, динамичный рост агропромыслового хозяйства и перерабатывающих отраслей АПК является важнейшим источником не только обеспечения качественными продуктами питания, решения продовольственной безопасности региона и страны, но и увеличения занятости, поддержания традиционного образа жизни и решения вопроса социальной защиты коренного населения [3]. Основные средства достижения целей регионального АПК - активизация инновационной деятельности, совершенствование организационно-экономического механизма ее регулирования, повышение уровня и качества жизни на селе [4].

В этой связи, учитывая сложившуюся концентрацию производства и инфраструктуры, предлагается следующие направления развития районов КЧР.

Во-первых, для горных районов КЧР - (Карачаевского и Зеленчукского, Малокарачаевского и Урупского) предлагается перенос экономического центра тяжести на туристско-рекреационную предпринимательскую среду, а АПК районов рассматривать как обеспечивающие туристско-рекреационный комплекс экологически чистыми продуктами в объемах и ассортименте, цене удовлетворяющие туристов и население [5].

\section{Литература:}

1. Статсборник «КЧР в цифрах» 2013г.

2. Предпринимательский климат регионов России. М.:Начала Пресс, 2012г.

3. Российский экономический журнал, 2013, №1.

4. investkavkaz.ru, «Стратегия социально-экономического развития СевероКавказского федерального округа до 2025 года»

5. minek-kchr.ru, «Инвестиционный план КЧР на 2013 год» 